\title{
口蓋裂早期手術後の言語成績
}

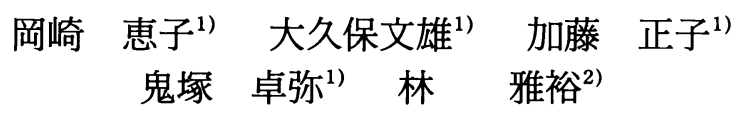

要 約 : 1986 1987 年に昭和大学形成外科において, 片側唇䂓口蓋裂児 10 例, 男 6 例, 女 4 例に対し, 生後 $3 \sim 4$ 力月時に唇裂と口蓋裂の同時手術を行った。これらを早期手術群とし, 同時期に唇裂を $3 \sim 4$ 力月，口蓋裂を $12 \sim 17$ 力月に手術を行った片側唇額口蓋裂児 48 例を対 照群として 4 歳時における言語成績を比較した。

(1)鼻咽腔閉鎖機能は早期手術群は全例，対照群は $92 \%$ が良好であった。

(2)早期手術群は全例構音は正常であったが, 対照群は 26 例, 54 \%に構音障害が認められた。 (3)早期手術群の $[\mathrm{p}],[\mathrm{t}],[\mathrm{k}],[\mathrm{t}] \mathrm{j},[\mathrm{s}],[\mathrm{s}]$ の構音習得年齢は, [k] を除いて対照群よ り早く，正常児の構音習得年齢とほほ同じであった。

(4)早期手術群の始語年齢, 二語文発話年齢の平均は対照群より早かった。

以上の結果より言語面からみると早期手術は有効であったといえる.

索引用語：口蓋裂，早期手術，同時手術，構音障害，鼻咽腔閉鎖機能

\section{Speech Attainment after Early Operation of Cleft Lip and Palate}

\author{
Keiko Okazaki ${ }^{1)}$, Fumio Ohkubo ${ }^{1)}$, Masako Kato ${ }^{1)}$ \\ Takuya Onizuka ${ }^{1)}$, Masahiro Hayashi ${ }^{2)}$
}

\footnotetext{
Abstract : Ten children (6 boys, 4 girls) with unilateral cleft lip and palate underwent a one-stage repair procedure at the age of 3-4 months at the Department of Plastic and Reconstructive Surgery of Showa University in 1985-6. The speech of this early operative group was compared with that of a group of 48 children with unilateral cleft lip and palate (reference group) who received an operation for cleft lip at the same age of 3-4 months and a separate operation for cleft palate at 11-17 months.

(1) Good velopharyngeal closure function was found in $100 \%$ and $92 \%$ of the cases of the early operative and reference groups, respectively.

(2) Articulation was normal in all cases in the early operative group, whereas articulation disorders were present in 26 cases $(54 \%)$ of the reference group.

(3) The age at which articulation of $/ \mathrm{p}, \mathrm{t}, \mathrm{k}, \mathrm{t} \mathrm{f}, \mathrm{S}, \mathrm{s} / \mathrm{was}$ mastered was earlier in the early operative group than in the reference group, with the exception of $/ \mathrm{k} /$, and was virtually

1) 昭和大学医学部形成外科： 142 東京都品川区旗の台 $1-5-8$

2) 鶴岡市立荘内病院形成外科：干 997 鶴岡市馬場町 2-1

1) Department of Plastic and Reconstructive Surgery, School of Medicine, Showa University : 1-5-8 H atanodai Shinagawa-

2) Department of Plastic Surgery, Tsuruoka Municipal Hospital : 2-1 Baba-cho, Tsuruoka 997.

原稿受理日：平成 2 年 10 月 24 日
} $\mathrm{Ku}$, Tokyo 142. 
the same as that of normal children.

(4) The mean age at which words were first spoken and 2-word phrases first uttered was earlier in the early operative group than in the reference group.

The above results indicate that early operative repair is useful from the point of view of speech development.

Key words : cleft palate, early operation, one-stage repair, articulation, velopharyngeal closure function.

\section{I 、はじめに}

口蓋裂の手術目的が正常言語の獲得にあることは周 知の事実である。その目的をはたすために, 手術方法, 手術年齢に関してさまざまな試みがなされてきた。手 術方法によっても異なるが, 手術年齢は, 通常, こと ばを話し始める 1 歳から 2 歳に行われている ${ }^{1-5)}$. しか しながら, 乳児は誕生した時点から泣き声を含めてさ まざまな音を産生していることを考えると，言語の立 場からいえば口蓋裂児が生まれた直後に口蓋の機能と 形態を正常に修復する口蓋形成術を行うことが望まし いといえる.われわれは, 生後 3 力月から 4 力月の唇 裂口蓋裂児に唇裂手術と同時に口蓋形成術を試みたの で，その言語成績を示し，口蓋裂手術の至適年齢に関 し若干の考察を加えて報告する。

\section{II. 手術方法と対象}

手術方法は, 唇裂手術時に同時に口蓋形成を行うも ので，われわれはこれを同時手術と称している，手術 法は生後 3 力月時に行っている rotaion advancement 法に小三角弁を加えた鬼塚法による口唇形成術 ${ }^{5)}$ と, 1 歳時に行っている Wardill-Kilner 法に準じた push back 法による口蓋形成術を同時に行うものである。

手術年齢は 3 力月から 4 力月である. 症例はすべて 片側唇䅡口蓋裂で, 満期産で出生時にとくに問題がな く, 体重が順調に増加し, ほほ $6 \mathrm{~kg}$ に達したものであ る。また，小児科的診察，血液一般および生化学検査 はいずれも特記すべきことはなかった，裂幅の程度に ついてはとくに考慮しなかった. 男 6 例, 女 4 例の 10 例で, 手術は 1985 年 6 月から 1986 年 10 月にかけて行
つた。術者は複数である。これらを早期手術群とした。 一方，同時期に当科で口蓋形成術を行った片側唇顓口 蓋裂児 48 例を対照群とした. 対照群は $3 \sim 4$ 力月時に 唇裂の手術を鬼塚法によって行い，11〜17 カ月時に Wardill-Kilner 法に準じた pushback 法で口蓋形成 手術を行ったものである（表 1 ）.

全例に遠城寺式乳幼児発達検査を施行し, 必要な症 例には田中ビネー知能検査, または WPPSI 知能検査 を行って, 精神発達に遅れがあるものは対象から除外 した。

\section{III. 評価方法}

$3 \sim 6$ 力月の間隔で言語治療士が定期的に鼻咽腔閉 鎖機能，構音および言語発達の評価を行った。

構音はすべて有意味語の中での構音を評価対象とし た。単語の絵カード 25 語を使用し ${ }^{8)}$ 自発話または復唱 により判定したが, 絵カードによる検査が不可能な場 合は, 自由会話の場面から聴取して判定した。今回は 構音のうち, $[\mathrm{p}],[\mathrm{t}],[\mathrm{k}],[\mathrm{t} \mathrm{j}],[\mathrm{s}],[\mathrm{s}]$ の習得年 齢を求めたが，これらの音が単語で構音可能になった 年齢を習得年齢とした。

鼻咽腔閉鎖機能は，日本音声言語医学会の鼻咽腔閉 鎖機能検查試案 ${ }^{7)}$ に基づいて, 開鼻声, blowing 検査, 口腔視診をおこない, 必要な場合は発話時の頭部側方 セファログラフならびに鼻咽腔ファイバー検査を施行 し, 鼻咽腔閉鎖機能を良好, 軽度不全, 不全の 3 段階 に分類した。

言語発達は言語発達のひとつの指標として始語年 齢, 二語文発話年齢を調査した. 最終評価年齢は 4 歳 から 5 歳である.

表 1 対象

\begin{tabular}{l|c|c|c|c}
\hline \multirow{2}{*}{} & \multicolumn{3}{|c|}{ 口蓋裂手術年齢 } & \multirow{2}{*}{ 症例数 } \\
\cline { 2 - 4 } & 範囲 & 平均 & 標準偏差 & \\
\hline 早期手術群 & $3 \sim 4$ 力月 & 3.6 力月 & 0.5 & 10 \\
対照群 & $11 \sim 17$ & 12.3 & 0.6 & 48 \\
\hline
\end{tabular}




\section{IV. 結 果}

\section{1. 重咽腔閉鎖機能}

早期手術群は全例鼻咽腔閉鎖機能は良好であった。 一方, 対照群は 48 例中 44 例, $91.6 \%$ が良好であった が，2例は軽度不全，1例は不全でいずれも経過観察 中である (表 2 )。

\section{2. 構音}

早期手術群は構音発達が正常に経過しており, 全例, 構音障害が認められなかった。一方, 対照群は構音障 害が認められなかったものは 26 例, $54.2 \%$, 経過観

表 2 鼻咽腔閉鎖機能

\begin{tabular}{l|l|l|l|l}
\hline 鼻咽腔閉鎖機能 & \multicolumn{1}{|c|}{ 良好 } & 軽度不全 & \multicolumn{1}{|c}{ 不全 } & 計 \\
\hline 早期手術群 & 10 & 0 & 0 & 10 \\
対照群 & $44(91.6)$ & $3(6.2)$ & $1(2.2)$ & 48 \\
\hline
\end{tabular}

（）内は\%

表 3 構音障害

\begin{tabular}{l|l|l|l|l}
\hline 構音障害 & \multicolumn{1}{|c|}{ なし } & \multicolumn{1}{|c|}{ あり } & 経過観察中 & 計 \\
\hline 早期手術群 & 10 & 0 & 0 & 10 \\
対照群 & $26(54.2)$ & $17(35.4)$ & $5(10.4)$ & 48 \\
\hline
\end{tabular}

（）内は\%

表 4 構音障害の内訳

\begin{tabular}{l|l}
\hline \multicolumn{1}{c|}{ 構音障害の種類 } & 症例数 \\
\hline 口蓋化構音 & 6 \\
口蓋化構音+側音化構音 & 2 \\
口蓋化構音+声門破裂音 & 1 \\
鼻咽腔構音 & $3(3)$ \\
鼻咽腔構音+側音化構音 & 1 \\
側音化構音 & 2 \\
声門破裂音 & $1(1)$ \\
子音の省略 & 1 \\
\hline \multicolumn{1}{c}{ 計 } & 17 \\
\hline
\end{tabular}

（）内は自然治癒した症例数
察中に構音障害が認められたものが 17 例， $35.4 \%$ お よび構音障害の疑いがあるが確定診断がつかずに経過 観察中のものが 5 例であった（表 3 ).

構音障害が確定した 17 例の内訳は表 4 に示した。鼻 咽腔構音の 3 例および声門破裂音の 1 例は経過観察中 に自然治瘾した（表 4 ）。

次に正常な構音発達の経過を示した早期手術群 10 例および対照群 26 例について個々の音の習得年齢を みた。

破裂音 $[\mathrm{p}]$ は早期手術群の半数は 1 歳 6 力月まで に, 全例が 2 歳までに習得した。対照群は早期手術群 よりやや遅れ 2 歳までに $73 \%$ ，全例が習得したのは 2 歳 6 カ月であった. [t] は早期手術群が 3 歳で $70 \%$, 3 歳 6 カ月までに全例が習得したのに対し対照群は 3

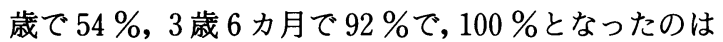
4 歳であった。 [k] は両群に大きな差がなく, 両群と も 3 歳で全例が習得した。

破擦音 [t $\mathrm{t}]$ は, 早期手術群が 2 歳 6 カ月で $80 \%$,

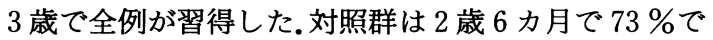
あったが，全例が習得したのは 4 歳であった（図 2 ).

摩擦音 [S] は早期手術群は 2 歳 6 力月で $50 \%, 3$ 歳 6 カ月で $100 \%$ に達しているのに対し, 対照群は 2 歳 6 カ月で $30 \% ， 3$ 歳で $60 \% ， 4$ 歳で $92 \%$ あ゙あた。 一方, [s] は, 早期手術群が 4 歳で $70 \%$, 対照群が 50 \%であった。

\section{3. 言語発達}

始語年齢の平均は早期手術群が 10.3 力月, 対照群が 11.4 カ月で約 1 カ月の差であった. また, 二語文発話 の平均年齢は 22.7 カ月であるのに対し, 後者は 24.5 カ月で早期手術群の方が約 2 カ月早かった。しかし, 始語年齢も二語文発話年齢も両群の間に統計的な有意 差はなかった $(\mathrm{p}<0.05)$.

\section{V. 考察}

\section{1. 同時手術について}

口唇裂と口蓋裂を同時に手術する方法は, 1966 年に Daviesが one-stage repairとして最初に報告し た ${ }^{8)}$. 片側唇額口蓋裂 20 例に対し, 生後 $5 \sim 6$ 力月時 に唇裂は Z 形成術, 口蓋裂は Wardill-Kilner の方法で

表 5 言語発達

\begin{tabular}{l|c|l|c|l|l|c}
\hline \multirow{2}{*}{} & \multicolumn{3}{|c|}{ 始語月齢 } & \multicolumn{3}{c}{2 語文発話月齢 } \\
\cline { 2 - 7 } & 範囲 & \multicolumn{1}{|c}{ 平均 } & 標準偏差 & \multicolumn{1}{|c|}{ 範囲 } & \multicolumn{1}{|c}{ 平均 } & 標準偏差 \\
\hline 早期手術群 & $7 \sim 12$ 力月 & 10.3 力月 & 1.7 & $18 \sim 27$ 力月 & 22.7 力月 & 2.5 \\
対照群 & $10 \sim 17$ & 11.4 & 2.0 & $18 \sim 39$ & 24.5 & 4.4 \\
\hline
\end{tabular}




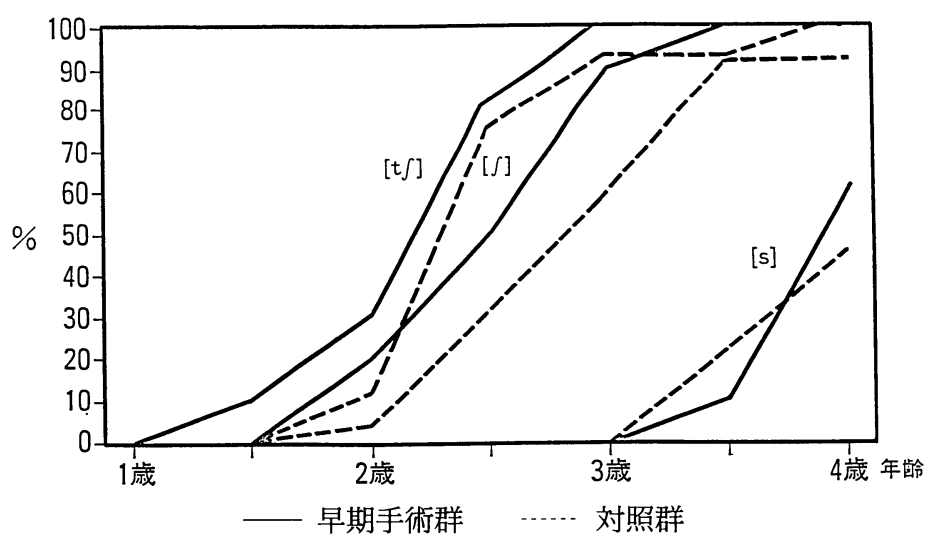

図 $1[\mathrm{p}],[\mathrm{t}],[\mathrm{k}]$ の習得過程

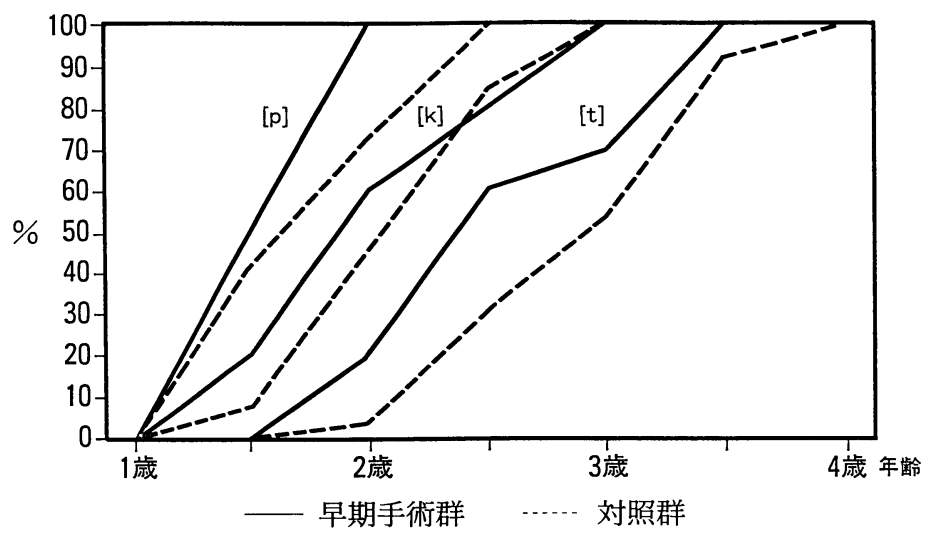

図 $2[\mathrm{ts}],[\mathrm{s}],[\mathrm{s}]$ の習得過程

行った。その後 1970 年にさらに症例を加え 50 例につ いて報告している ${ }^{9)}$. 彼は同時手術の目的として手術 回数と麻酔回数の減少および手術の単純さをあげてい る.しかし，術後の言語成績や咬合については具体的 な記述がない.

その後, Kaplan, I が 1970 年から 1972 年にかけて行 つた同時手術を simultaneous repair として 1973 年 に報告している ${ }^{10)} .13$ 例の唇顎口蓋裂患者に $3 \sim 4$ 力 月時に同時手術を行い，唇裂は Le Mesurier または Millard の方法で形成し，口蓋は Langenbeck 法を採 用している.さらに症例を加え, 調査可能であった 28 例について 10 年後の成績を報告している ${ }^{11,12}$. 心理面 で母親の過保護が少なく良好な育児環境にあったこ と, 顁発育は collapse もなく, 咬合, 歯列も正常であ り, スピーチは 18 例が excellent, 9 例が satis-factory, 1例が poor であったとしている.

このように同時手術に関する論文は, 手術年齢が早 期であることが言語成績にどのような影響を及ほすか
ということよりは，唇裂と口蓋裂を同時に手術した場 合の手術時間, 手術手技, 麻酔, 出血量など手術に重 点がおかれている。われわれの場合手術に関して，口 唇と口蓋の手術が同時にできる, 口唇と口蓋を分けて 行う場合に比べて手術視野が広く手術がやりやすい, 出血量が少ない（約 $20 \mathrm{cc}$ ), 手術時間が思ったほど長 くない(約 2 時間), 瘦孔ができにくい(瘦孔残存例は なかった）などいくつかの利点を経験したが，本論文 は言語成績の報告を目的としているので, 手術に関し ては稿を改めて報告したい.

\section{2. 早期手術における言語成績}

今回の同時手術は口蓋の手術が生後 $3 \sim 4$ 力月で行 われたことから, 早期に口蓋形成を行った場合の言語 成績という観点から考察をすすめたい.

早期手術を考える場合，まず，早期の概念を規定す る必要がある. 口蓋裂の手術が 1 歳代で行われた場合 はもちろんのこと，3歳未満の手術例についても早期 手術ということばが使用されている ${ }^{1,13,14)}$ が,ここでは 
遅くとも生後 7 ～ 8 カ月までに口蓋形成を行った場合 を早期手術とした.

先に述べたように, Kaplan, I は生後 $3 \sim 4$ 力月に 同時手術で口蓋形成を行い, 28 例中 poor と判定した のが 1 例であったと報告している ${ }^{12)}$.

同時手術以外の早期手術としては次のものがある. Holdsworth は, 手術方法は一定していないが, 手術年 齢を $6 \sim 9,10 \sim 12,13 \sim 15,16 \sim 18$ 力月に分類し, $6 \sim 9$ 力月の症例は 10 力月以上の手術年齢群に比較 して, 正常なスピーチの比率がきわめて高いことを報 告している ${ }^{15)}$. Evans らは Wardill-Kilner の V-Y の 術式により口蓋形成を行い, 8 力月以前, $8 \sim 10$, 11 13，14〜30 カ月の手術群に分類し，8 カ月以前の 手術群は他の群に比較して, 開鼻声や構音障害の発現 頻度が低かったとしている ${ }^{16)}$. また, Dasai は口唇口蓋 裂患者 100 例に対し, 唇裂を生後 48 時間以内に, 口蓋 裂を 16 週間以内で行っているが, スピーチに関しては 開鼻声を示した症例がなかったと記述している ${ }^{17)}$. Dorf らの場合 ${ }^{18}$ は早期手術群を $5 \sim 12$ 力月，晚期手 術群を 12〜27 カ月として言語成績を比較している.構 音障害の分類は Trost ${ }^{19}$ にならい. mid-dorsom palatal stops, posterior nasal fricatives, pharyngeal stops, pharyngeal fricatives, glottal stops を代償構 音とし, その発現頻度を求めている。 その結果, 代償 構音は早期手術群 $10 \%$ に対し, 晚期手術群は $86 \%$ の 高い発現頻度で, 両群に大きな差が認められた。

以上のように, 手術方法, 手術年齢, スピーチの評 価方法は異なるが，文献上，早期手術群は概して言語 成績がよいといえる。とくに，われわれの構音障害の 分類に比較的近似した分類を用いているDorf の報告 は, 今回のわれわれの成績を支持するものといえよう。 正常児の場合, 音声学的に種々の母音や子音の形成 が盛んになるのは 6 〜 9 月であるといわれてお $\eta^{18,20,21)}$ ，その意味では 6 力月以前に口蓋形成を行い, 正常児により近い口腔形態と機能を修復することが望 ましい. Kaplan, E.N.は ${ }^{22)}$ 神経システムや筋肉のコン トロールには学習の適期があり, 口蓋の修復が遅れる と，8～9 カ月までに異常な構音パタンを学習し, 手 術後も継続するとしている.さらに口蓋形成術後, 浮 腫や瘷痕によって軟口蓋の動きが制限されることを考 慮して，3〜 6 カ月が手術の至適年齢であると結論し ている. しかし，実際には一部の手術機関を除いて 3 〜 6 カ月に口蓋形成が行われていないのは，早期に口 蓋に手術侵襲を加えることは，正常な顖発育を阻害す るという報告 ${ }^{4,25)}$ もあり, 額発育に対する配慮からであ ろう。つまり，良好な額発育と正常なスピーチは二律
背反の関係にあると考えられている．そのために術者 は手術法や手術年齢についてさまざまな工夫をしてい $る^{25 \sim 30)}$.

通常, 口蓋裂の手術はスピーチと蕷発育の両方を考 慮して 1 歳代で行われることが多い. しかし，1歳代 の手術例の術後の言語成績をみると, 鼻咽腔閉鎖機能 良好例の比率がきわめて高いにもかかわらず, 構音障 害の発現頻度は高く, およそ $50 \%$ 近くを占め, 中でも 口蓋化構音の発現頻度が高い ${ }^{1,31 ~ 33)}$. 口蓋化構音は, 術 後の口蓋が浅く，とくに前方部の歯列が狭窄している 症例に多( ${ }^{34)}$ ことから口蓋の形態の異常が口蓋化構音 の発現の原因の 1 つと考えられている．4 歳の現時点 での額発育は, 早期手術群は対照群の症例に比較しほ ほ同じかややわるい傾向がみられた，それにもかかわ らず対照群の構音障害の発現は, 48 例中 17 例で, その うち 9 例が口蓋化構音であったのに対し, 早期手術群 は全例が構音正常であった。このことは，早期の口蓋 形成により正常児に近い魷下動作, 喃語の構音が可能 となり，ひいては正常な構音発達につながったという 推測が成り立つ。

しかしながら, 今回の結果は 10 例というきわめて少 数例であり, 喃語の構音分析も行っていないので, 先 に述べたことはあくまでも推測の域をでていない。口 蓋裂児のケアを考える場合，正常なスピーチの習得だ けではなく，より正常な顥発育も考慮していかなけれ ばならない。晾登育は手術法や手術年齢だけではなく, 術前の裂型, 唇裂の手術, 個体のもつ発育の因子, 学 習能力などいくつかの因子が影響し $20,21,24,35)$, 複雑な 要素を含んでいる. 今後, 長期にわたる額発育の経過 をみることによって，はじめて口蓋裂手術の至適年齢 に関する結論が出せることになるといえよう。

\section{3. 柾音発達ならびに吾語発達について}

今回，破裂音の $[\mathrm{p}][\mathrm{t}][\mathrm{k}]$ ，破擦音の $[\mathrm{t} \mathrm{t}]$ および 摩擦音の [s], [s] の習得過程を対照群と比較した。そ の結果, [s]は構音発達の途上にあるので今後の経過観 察が必要であるが, [k] を除いて他の音の習得年齢は 早期手術群の方が対照群より早い傾向がみられた。

口蓋裂児は，正常児と比較して構音障害の発現頻度 が高いだけではなく，構音の習得が遅れるといわれて いる ${ }^{36)}$. 井上ら ${ }^{37}$ は, 1 歳 1 力月で口蓋形成を行った左 唇裂口蓋裂児 1 例の喃語期の構音発達を 6 力月から 20 力月まで追跡しているが，口蓋裂児は健常児に比較 して全体に構音発達は遅れ，とくに歯音または歯茎音, 歯茎硬口蓋音は 20 力月までほとんど構音されていな いとしている.

正常児の有意味語における構音習得年齢について中 
西ら ${ }^{38)}$, 船山ら ${ }^{39)}$ が報告しているが, いずれも横断的調 査であり，基準が異なるので直接比較はできない，正 常児 10 例の構音発達について追跡調査した大和田ら の報告は正常構音の初発年齢と $90 \%$ 以上恒常となっ た年齢をあげている ${ }^{40)} .[\mathrm{p}],[\mathrm{t}],[\mathrm{k}]$ は 1 例を除い て 1 歳 6 力月までに構音しており，2 歳 6 力月から 2 歳 8 カ月で完成している. [ts], [s] は 2 歳までに構音 が始まり, [t $]$ は 2 歳 9 カ月で完成し, [S] は 4 歳まで に完成している。資料収集の方法は異なるが，90\%恒 常となった年齢で比較すると, 早期手術群は $[\mathrm{t}]$ の習 得にやや遅れがみられたが, 正常児にほほみあった構 音習得を示していた。一方，対照群は $[\mathrm{t}] ，[\mathrm{t} \mathrm{t}]$ の習 得が遅れ，[S] の習得にもやや遅れがみられた。

以上のことから，正常構音を習得した口蓋裂児であ っても，正常児に比べてとくに歯茎音の習得に遅れが みられたが，早期の口蓋形成が，正常児により近い構 音習得に関連していることを示唆しているといえよ う.

また，言語発達に関しては同時手術を行った Kaplan, I が，同時期に 10〜12 カ月で口蓋形成を行った 口蓋裂児と比較し，始語年齢も $2 \sim 3$ 語発話の年齢も 早く正常児と変わらなかったと述べている ${ }^{10)}$. われわ れの場合は始語と二語文発話の平均年齢は対照群に比 較して早期手術群が早かったが, 両群に統計的な有意 差はなく, 両群とも正常児の言語発達にほほみあった 発達を示していた。言語発達に関しては，単に始語お よび二語文発話の年齢だけではなく，さらに詳細な検 討が必要であると考えている。

\section{VI.まとめ}

$3 \sim 4$ 力月時に唇裂と口蓋裂を同時に手術した片側 唇顎口蓋裂児 10 例の言語成績を 4 歳まで追跡調查し た結果, 以下のことが明らかになった。

(1)術後の鼻咽腔閉鎖機能は，全例良好であった。

(2)構音発達はほほ正常に経過していた。

(3)構音障害を示した症例は 1 例もなかった。

本論文の要旨の一部は第 34 回日本音声言語医学会 (名古屋) で 発表した。

\section{文献}

1) Ainoda N, Yamashita K, Tsukade S : Articulation at age 4 in children with early repair of cleft palate. Annals of Plastic Surgery, $15: 415$ $-422,1985$.
2）赤川徹弥：口蓋裂初回手術。形成外科，28：285289, 1985.

3）宮崎 正：口蓋裂 その基礎と臨床．医歯薬出版, 1982, p 299-303.

4) Watson, A.C.H. : Primary surgery. Advances in the Management of Cleft Palate in edited by Edwards and Watson A.C.H. Churchill Livingstone, Edinburgh London, 1980, pp 134-165.

5）鬼塚卓弥：形成外科手術書. 南江堂, $1980, \mathrm{pp} 589$ -612 .

6）熊井和子, 相野田紀子, 阿部雅子・他：口蓋裂言 語の検査法について一構音検査に関する試案一. 音声言語医学, $26 ： 169-173 ， 1984$.

7）阿部雅子, 相野田紀子，岡崎恵子・他：口蓋裂言 語の検査法について一鼻咽腔閉鎖機能検査法に関 する試案一。音声言語医学， $21 ： 148-155 ， 1980$.

8) Davies, D. : The one-stage repair of unilateral cleft lip and palate : A preliminary report. Plast and Reconstr Surg, 38 : 129-136, 1966.

9) Davies, D. : The radical repair of cleft palate deformities. Cleft Palate J., $7: 550-561,1970$.

10) Kaplan. I, Drener, J., Gorodischer, $C$ et al. : The simultaneous repair of cleft lip and palate in early infancy. Brit. J. of Plastic Surgery. $27: 134$ $-158,1973$.

11) Kaplan, I, Taube, E., Ben-Bassat, M., et al. : Further experience in the early simultaneous repair of cleft lip and palate. Brit. J. Plastic Surgery, 33 : 299-300, 1980.

12) Kaplan, I, Ben-Bassat, M., Taube, E, et al. : Ten -year follow-up of simultaneous repair of cleft lip and palatein infancy, Annals of Plastic Surgery, $8: 227-228,1982$.

13）相野田紀子，阿部雅子：口蓋裂早期手術例と晚期 手術例における構音の比較。音声言語医学, 27 : 287-291， 1986.

14）江口実美,道祖尾卓而：口蓋裂早期手術例の検討. 耳鼻臨床，64：846-852，1971.

15) Holdsworth, W.G. : Early treatment of cleft-lip and cleft-palate. Brit Medical J, $11: 304-308$, 1954.

16) Evans D. and Renfrew.C. : The timing of primary cleft palate repair. Scand J Plast Reconstr Surg, 8 : 153-155, 1974.

17) Desai, S.N. : Early cleft palate repair completed before the age of 16 weeks : observations on a 
personal series of 100 children. Brit J Plast Surg. $36: 300-304,1983$.

18) Dorf, D.S. and Curtin, J.W. : Early cleft palate repair and speech outcome. Plast Reconstr Surg, $70: 74-79,1982$.

19) Trost, J.E. : Articulatory additions to the classical description of the speech of persons with cleft palate. Cleft Palate J., 18 : 193-203, 1981.

20) Bzoch, K.R. : Etiological factors related to cleft palate speech. In Communicative Disorders Related to Cleft Lip and Palate (2nd Ed.), edited by Bzoch, 67-76, Little Brown \& Co. Boston, 1977.

21) McWilliams, B.J. : Articulation and intelligibility. In Cleft Palate Speech edited by McWilliams, B.J., Morris, H.L. and Shelton R.L. pp 232 -255, B.C. Decker Inc, Philadelphia, Toronto, 1984.

22) Kaplan, E.N. : Cleft palate repair at three months?. Annals of Plast Surg, 7 : 179-190, 1981.

23) Schultz, L.W. : Early closure of cleft lip and palate. Amer. J. Surg., $100: 869-873,1960$.

24) Randall; P., LaRossa, D.D., Fakhraee. S.M., et al. : Cleft palate closure at 3 to 7 months of age : A preliminary report. Plast Reconstr Surg., 71 : 624-627, 1983.

25）上石 弘：口蓋粘膜弁による口蓋形成術. 形成外 科, $28: 790-796,1985$.

26) Schweckendiek, W. : Primary veloplasty : Long -term results without maxillary deformity. A twenty-five year report. Cleft Plate J., 15 : 268 $-275,1978$.

27) Cosman, B. and Falk, A.S. : Delayed hard palate repair and speech deficiencies : A cautionary report. Cleft Palate J., $17: 27,33,1980$.

28) Jackson, I.T., McLennan, G. and Scheker, L.R. : Primary veloplasty or primary palatoplasty : some preliminary findings. Plastic and Reconstr surg., $72: 153,187,1983$.

29）長田光博, 谷野隆三郎, 西村正樹 - 他：われわれ の行っている口蓋裂二期手術 (長田法). 形成外科, 28:290-299, 1985.
30）塚田貞夫：私の行っている口蓋裂初回手術- $\mathrm{Pal}$ atal pushback 法における軟口蓋の完全可動化. 形成外科, $28: 270-277,1985$.

31）岡崎恵子，加藤正子，鬼塚卓弥・他：口蓋裂初回 手術後の言語成績. 日口蓋誌, $10 ： 161-168,1985$.

32）鈴木恵子, 岡本朗子, 原 由紀 - 他：口蓋粘膜弁 法の術後言語成績. 日口蓋誌, $14: 123-131,1989$.

33）吉増秀実, 大平章子, 塩田重利 -他：唇 - 顎 -口 蓋裂患者に対する初回口蓋形成手術の遠隔成績 第 1 報 1 歳台および 2 歳台手術例の言語成績に ついて. 日口蓋誌，11：62-79，1986.

34) Okazaki, K, Kato, M, Onizuka, T : Palate morphology in children with cleft palate with palatalized articulation. Annals of Plast Surg, 26 : 156-163, 1991.

35) Ward, R.E, Bixler, D and Faywood, E.R. : A study of cephalometric features in cleft lip-cleft palte families : phenotypic heterogenesity and genetic predisposition in parents of sporadic cases. Cleft Palate J., 26 : 318-326, 1989.

36) Riski, J.E, \& DeLong, E. : Articulation development in children with cleft lip/palate. Cleft Palate J., $21: 57-64,1984$.

37）井上 幸, 国吉京子, 平野信子 - 他：唇裂口蓋裂 児一症例における喃語期の構音と心身の発達。日 口蓋誌，14：358-365，1989.

38）中西靖子, 大和田健次郎, 藤田紀子 : 構音検査と その結果に関する考察. 特殊教育研究施設報告, $1: 1-41,1972$.

39）船山美奈子，阿部雅子，加藤正子・他：構音検査 法に関する追加報告. 音声言語医学, $30 ： 285-292$, 1989.

40）大和田健次郎，中西靖子 : 幼児のことばの発達(6) 一構音の恒常性と完成順位一.耳喉, $43: 183-193$, 1971.

41）村田孝次：幼児の言語発達. 培風館, $1978, p p 129$ -151 .

\section{別刷請求先：テ 142 東京都品川区旗の台 1-5-8 昭和大学形成外科 岡崎恵子}

